\title{
Persiapkan Siswa SMK Terampil melalui Pelatihan Kompetensi Kejuruan Teknologi Motor Diesel
}

\author{
Toto Sugiarto ${ }^{1}$, Wawan Purwanto ${ }^{2}$ Bahrul Amin ${ }^{3}$ \\ 123Jurusan Teknik Otomotif/ Fakultas Teknik/Universitas Negeri Padang \\ *)Corresponding author, $\equiv$ totosugiarto@ft.unp.ac.id
}

Revisi 25/06/2019; Diterima 15/07/2019; Publish 08/08/2019

Kata kunci:Sekolah Menengah Kejuruan, Kualitas Lulusan, Kompetensi Kejuruan, Teknologi Motor Diesel

\begin{abstract}
Abstrak
Sekolah Menengah Kejuruan bertujuan untuk mampu menyiapkan peserta didik yang kreatif, menguasai ilmu pengetahuan dan teknologi, serta memiliki kompetensi yang sesuai dengan tuntutan dunia kerja. Kualitas lulusan SMK tidak hanya ditentukan oleh faktor individu dari siswa itu sendiri, akan tetapi juga sangat ditentukan oleh faktor dari luar, salah satunya komptensi pendidikan yang bisa menyiapkan lulusan sesuai dengan tuntutan dunia kerja. Program Kemitraan bagi Masyarakat (PKM) bertujuan untuk memberikan pelatihan Peningkatan Kompetensi Kejuruan Teknologi Motor Diesel bagi Guru dan Siswa SMK di kabupaten Solok, kegiatan PKM dengan tema Peningkatan Kompetensi Kejuruan Teknologi Motor Diesel bagi Guru dan Siswa SMK, dapat meningkatkan pengetahuan dan keterampilan peserta pelatihan sebesar 15,45\% dibidang kompetensi kejuran Teknologi Motor Diesel.
\end{abstract}

\section{PENDAHULUAN}

\section{Analisis Situasi}

SMK membekali siswanya dengan sederet ilmu praktis untuk mencetak tenaga kerja siap pakai yang terampil. Istilah kejuruan berhubungan erat dengan karir. Sekolah kejuruan juga dapat dipandang sebagai pendidikan teknis yang secara langsung mengembangkan keahlian siswanya dalam bidang tertentu. Undang-undang Nomor 20 Tahun 2003 tentang Sistem Pendidikan Nasional dalam penjelasan pasal 15 menyebutkan bahwa pendidikan kejuruan merupakan pendidikan yang mempersiapkan peserta didik terutama untuk bekerja dalam bidang tertentu. Peraturan Pemerintah Nomor 29 Tahun 1990 tentang Pendidikan Menengah, Pasal 1 ayat 3 menyebutkan pendidikan kejuruan adalah pendidikan pada jenjang menengah yang mengutamakan pengembangan kemampuan siswa untuk melaksanakan jenis pekerjaan tertentu.

SekolahMenengah Kejuruan bertujuan untuk mampu menyiapkan peserta didik yang kreatif, menguasai ilmu pengetahuan dan teknologi, serta memiliki kompetensi yang sesuai dengan tuntutan dunia kerja. SMK tidak hanya membentuk kemampuan kognitif, lebih dari itu 
membentuk mentalitas peserta didik yang terintegralisasikan dengan baik kemampuan praktis, teoritis, maupun kompilasi keduanya. Dengan demikian Sekolah Menengah Kejuruan dapat menjembatani problematika dunia kerja tingkat menengah di Indonesia

SMK Negeri 1 Gunung Talang dan SMK Negeri 1 Pantai Cermin Kabupaten Solok merupakan sekolah yang menyiapkan lulusannya mencapai lulusan yang memenuhi tuntutan dari tujuan pendidikan SMK yang telah ditetapkan oleh pemerintah. Kualitas lulusan SMK tidak hanya ditentukan oleh faktor individu dari siswa itu sendiri, akan tetapi juga sangat ditentukan oleh faktor dari luar, salah satunya komptensi pendidikan yang bisa menyiapkan lulusan sesuai dengan tuntutan dunia kerja.ProgramSMK bisa yang dicanangkan pemerintah, untuk menciptakan tenaga kerja siap pakai, telah menaikkan minat masyarakat pada pendidikan menengah kejuruan. Perkembangan jumlah SMK pun mengalami peningkatan, baik SMK pemerintah maupun SMK swasta. Peningkatan kualitas SMK ternyata tidak dibarengi dengan peningkatan kualitas lulusannya. Masih banyak tamatan SMK yang tidak bekerja.

Renstra Kemendikbud 2015-2019, menyatakan arah kebijakan pembangunan pendidikan nasional adalah menyelaraskan kebutuhan Dunia Usaha (DU)/ Dunia Industri (DI). Program SMK bisa yang dicanangkan oleh pemerintah, tidak semua SMK yang bisa mewujudkannya. Ini terlihat dari beberapa SMK yang ada di kabupaten Solok, masih belum relevannya kompetensi lulusan dengan kebutuhan DU/DI, sehingga pada saat mereka lulus, mereka tidak siap bekerja, dan perusahaan yang menerima mereka juga keberatan.

Penyelarasan kompetensi lulusan SMK terhadap kebutuhan DU/DI tidak terlepas dari sumber daya yang ada disekolah tempat mereka menimba ilmu. Sekolah-sekolah yang sudah mapan dan sudah lama berdiri, dari segi peralatan praktekum yang digunakan untuk materi pembelajaran yang sesuai dengan kisi-kisi Lomba Kompetensi Siswa (LKS) Akan tetapi berbeda kondisinya dengan sekolah-sekolah yang ada di daerah-daerah terpencil, seperti di kabupaten Solok. Hasil observasi yang telah penulis lakukan pada beberapa SMK yang ada di kabupaten Solok, yaitu di SMK Negeri 1 Gunung Talang dan SMK Negeri 1 Pantai Cermin, Kami menemukan beberapa aspek yang menghambat program SMK bisa, yaitu : Kondisi workshop jurusan teknik otomotif yang belum tertata dengan baik dan belum sesuai dengan standar pelayanan minimal (SPM) workshop Sekolah Menengah Kejuruan (SMK), kondisi peralatan praktek juga belum lengkap dan beberapa peralatan sudah rusak dan tidak dapat digunakan untuk pembelajaran praktekum, kemampuan guru-guru jurusan otomotif yang masih kurang dalam penguasaan teknologi terbaru di bidang otomotif, juga rendahnya motivasi guru-guru dalam proses kegiatan belajar mengajar.

Melalui kegiatan Program Kemitraan Masyarakat (PKM) yang diselenggarakan oleh Lembaga Penelitian dan Pengabdian kepada Masyarakat (LP2M) Universitas Negeri Padang, maka penulis tertarik untuk memberikan "Pelatihan Peningkatan Kompetensi Kejuruan Teknologi Motor Diesel bagi Guru dan Siswa Program Studi Teknik Otomotif SMK di Kabupaten Solok. Dengan pelatihan ini diharapkan nantinya kompetensi tamatan SMK yangakan memasuki lapangan kerja atau DU/DI bisa terpenuhi dan mendapatkan respon yang positif. Sehingga, slogan pemerintah SMK BISA betul-betul tercapai, artinya lulusan SMK bisa langsung bekerja setelah mereka tamat, dengan kompetensi sesuai dengan yang dibutuhkan oleh industri (Lapangan kerja).

\section{Solusi dan Target}

Untuk menyelesaikan permasalahan-permasalahan yang terjadi di sekolah mitra, ada beberapa solusi yang dapat dilakukan, yaitu:

1. Melakukan pembenahan dan penataan workshop jurusan otomotif di sekolah mitra yang dapat dilakukan oleh warga sekolah dibantu oleh tim pengabdian PKM, dengan tujuan agar

Persiapkan Siswa SMK Terampil melalui Pelatihan KompetensiKejuruan Teknologi Motor 
workshop sekolah mitra tertata rapi dan memenuhi standar pelayanan minimal workshop SMK. Pembenahan dapat dilakukan dengan membersihkan workshop dan merapihkan peralatan sesuai dengan kelompok pekerjaannya.

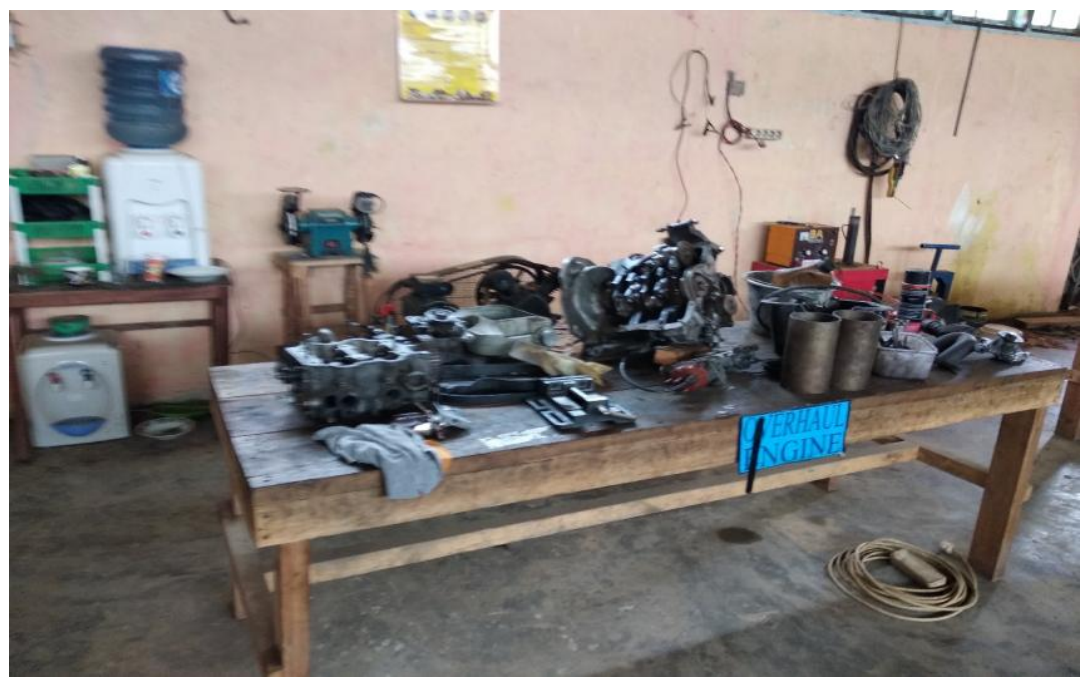

Gambar 1. Peralatan yang tidak pada tempatnya (Workshop sekolah mitra)

2. Melakukan perawatan dan perbaikan peralatan praktikum yang ada di workshop jurusan otomotif, banyak peralatan yang ada di workshop tidak berfungsi dan tidak dapat digunakan untuk kegiatan praktekum. Dengan adanya kegiatan pengabdian kepada masyarakat Program Kemitraan Masyarakat, tim pengabdi dan guru-guru serta siswa sekolah mitra melakukan perbaikan peralatan praktikum yang tidak berfungsi.

3. Memberikan pelatihan bagi guru dan siswa sekolah mitra tentang teknologi terbaru di bidang otomotif, materi terbaru yang diberikan pada guru dan siswa yaitu tentang sistem bahan bakar diesel dengan kontrol elektronik atau Common Rail System.

4. Memberikan pelatihan kompetensi kejuruan yang Teknologi Motor Diesel bagi guru dan siswa di sekolah mitra. Kegiatan ini dilakukan, karena terbatasnya peralatan untuk praktikum teknologi motor diesel. Untuk mendukung kegiatan ini tim pengabdi membawa peralatan dan bahan dari kampus, pelatihan yang akan diberikan yaitu: pembongkaran dan pemasangan kepala silinder motor diesel, pembongkaran dan pemasangan piston assembly, pembongkaran dan pemasangan pompa injeksi motor diesel, pembongkaran dan pemasangan serta penyetelan tekanan kerja injektor, menghidupkan motor diesel 4 silinder dan membuang udara dari sistem bahan bakar, pembongkaran sistem pemanas mula, pengukuran tekanan kompresi motor diesel, dan pengenalan bagian-bagian sistem bahan bakar diesel dengan kontrol elektronik (common rail system). 


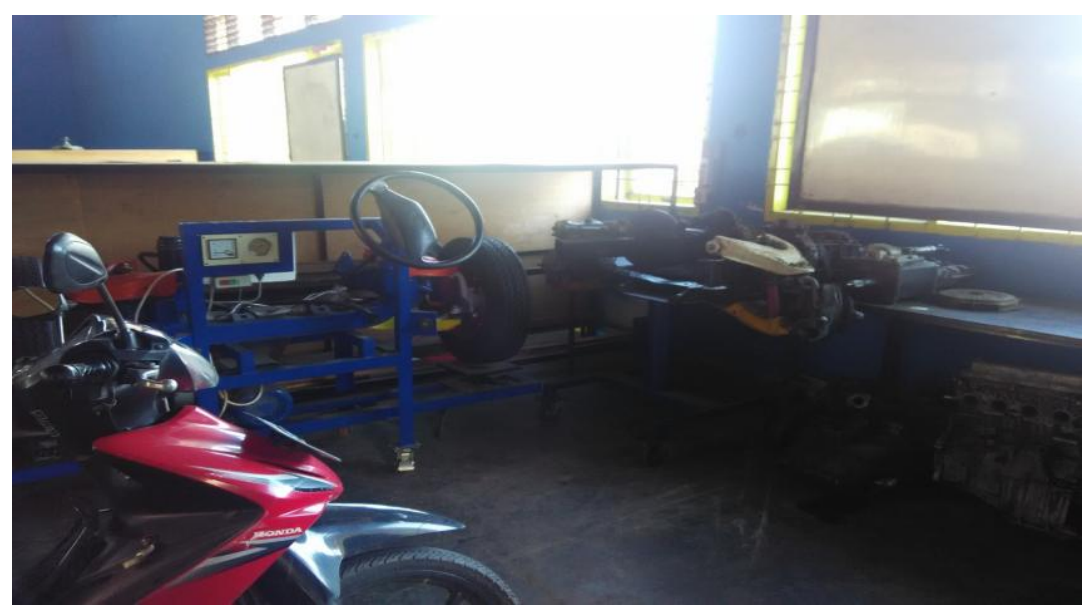

Gambar 2. Peralatan praktikum dalam kondisi tidak berfungsi (Workshop sekolah mitra)

Untuk melaksanakan kegiatan pengabdian kepada masyarakat melalui Program Kemitraan Masyarakat (PKM) dilakukan dalam tahapan-tahapan sebagai berikut:

\section{Tahap Persiapan}

a. Survey lapangan ke SMK Negeri 1 Gunung Talang dan SMK Negeri 1 Pantai cermin Kabupaten Solok Jurusan Teknik Otomotif, untuk mengidentifikasi khalayak dan ketepatan sasaran.

b. Menyusun proposal kegiatan pelatihan oleh tim pelaksana kegiatan.

c. Merencanakan bidang pelatihan, tentang "Pelatihan Peningkatan Kompetensi Kejuruan Teknologi Motor Diesel bagi guru dan siswa Program Studi Teknik Otomotif SMK di Kabupaten Solok..

d. Membuat program pelatihan.

e. Penentuan Peserta Pelatihan.

Supaya kegiatan ini lebih efektif, maka peserta pelatihan dalam kegiatan ini ditetapkan siswa SMK Negeri 1 Gunung Talang, yang diwakili oleh 20 orang siswa dan guru.

f. Kegiatan berikutnya adalah menetapkan materi pelatihan, yang berhubungan dengan Kompetensi Kejuruan Teknologi Motor Diesel.

\section{RencanaKegiatan}

Kegiatan pelatihan ini dilaksanakan selama 4 (empat) hari, yaitu Kamis, Jumat, Sabtu dan Minggu, pada tanggal 22, 23, 24 dan 25 Agustus 2019. Kegiatan dilaksanakan di workshop Jurusan Otomotif SMK Negeri 1 Gunung Talang Kabupaten Solok. Materi pelatihan yang akan diberikan meliputi : Sejarah Motor Diesel, Perbedaan Motor diesel dengan motor bensin, Cara kerja motor diesel 4 langkah dan 2 langkah, Komponen-komponen utama motor diesel, Proses pembakaran motor diesel, Sistem pemasukan udara, turbo charger dan inter cooler, Sistem pelumasan dan pendinginan, Sistem Bahan Bakar Motor Diesel konvensional dan Sistem Bahan Bakar Diesel dengan kontrol elektronik (Common Rail System). Pembongkaran dan pemasangan kepala silinder, pembongkaran dan pemasangan piston assembly, pembongkaran dan pemasangan pompa injeksi, pembongkaran dan pemasangan poros nok, pembongkaran dan pemasangan injektor, dan penyetelan saat penginjeksian, pembongkaran dan pemasangan serta penyetelan tekanan kerja injektor, menghidupkan motor diesel 4 silinder dan membuang udara dari sistem bahan bakar, pembongkaran sistem pemanas mula, pengukuran tekanan kompresi motor diesel, dan pengenalan bagian-bagian sistem bahan bakar diesel dengan kontrol elektronik (common rail system). Untuk lebih jelasnya dapat dilihat pada tabel 1 di bawah ini. 
Tabel 1. Materi Pelatihan Kompetensi Kejuruan Teknologi Motor Diesel

\begin{tabular}{clc}
\hline No & \multicolumn{1}{c}{ Materi Pelatihan } & Jumlah jam \\
\hline 1 & Sejarah Motor Diesel & 2 \\
2 & Perbedaan Motor Diesel dengan Motor Bensin & 2 \\
3 & Keuntungan dan kerugian Motor Diesel & 2 \\
4 & Cara Kerja Motor Diesel 4 langkah & 2 \\
5 & Cara Kerja Motor Diesel 2 langkah & 2 \\
6 & Sistem Pemasukan Udara, Turbo Charger, Super charger & 2 \\
7 & Sistem pelumasan dan sistem pendinginan & 2 \\
8 & Sistem bahan bakar motor diesel 1 silinder dan 4 silinder & 2 \\
9 & $\begin{array}{l}\text { Pompa injeksi model in line dan model ditributor } \\
10\end{array}$ & Sistem injeksi bahan bakar diesel dengan kontrol elektronik \\
11 & $\begin{array}{l}\text { Pembongkaran dan pemasangan kepala silinder serta piston } \\
\text { assembly }\end{array}$ & 2 \\
12 & $\begin{array}{l}\text { Pembongkaran dan pemasangan pompa injeksi dan } \\
\text { penyetelan injektor }\end{array}$ & 4 \\
13 & $\begin{array}{l}\text { Pembogkaran dan pemasangan poros nok dan crank case } \\
\text { engine }\end{array}$ & 4 \\
15 & $\begin{array}{l}\text { Pemeriksaan busi pijar dan pengukuran tekanan kompresi } \\
\text { Juman sistem bahan bakar dan tune up motor diesel }\end{array}$ & 4 \\
\hline
\end{tabular}

Target dari kegiatan pelatihan ini adalah:

1. Dapat meningkatkan motivasi guru dan siswa SMK program studi Teknik Otomotif di Kabupaten Solok untuk meningkatkan dan mengembangkan keterampilannya di bidang otomotif, terutama bidang Teknologi Motor Diesel yang perkembangannya sangat pesat pada kendaraan.

2. Tertatanya workshop jurusan otomotif sekolah mitra sesuai dengan Standar Pelayanan Minimal (SPM) workshop Sekolah Menengah Kejuruan (SMK).

3. Dapat beroperasi dan bisa digunakan kembali peralatan praktikum yang ada di workshop jurusan Teknik Otomotif di sekolah mitra.

4. Dapat meningkatkan pengetahuan dan ketrampilan guru dan siswa peserta pelatihan tentang Sejarah Motor Diesel, Perbedaan Motor diesel dengan motor bensin, Cara kerja motor diesel 4 langkah dan 2 langkah, Komponen-komponen utama motor diesel, Proses pembakaran motor diesel, Sistem pemasukan udara, turbo charger dan inter cooler, Sistem pelumasan dan pendinginan, Sistem Bahan Bakar Motor Diesel konvensional dan Sistem Bahan Bakar Diesel dengan kontrol elektronik (Common Rail System). 
5. Mampu membongkar, memasang, mendiagnosa dan menemukan kerusakan pada motor diesel, dengan pekerjan sebagai berikut: Pembongkaran dan pemasangan kepala silinder, pembongkaran dan pemasangan piston assembly, pembongkaran dan pemasangan pompa injeksi, pembongkaran dan pemasangan poros nok, pembongkaran dan pemasangan injektor, dan penyetelan saat penginjeksian, pembongkaran dan pemasangan serta penyetelan tekanan kerja injektor, menghidupkan motor diesel 4 silinder dan membuang udara dari sistem bahan bakar, pembongkaran sistem pemanas mula, pengukuran tekanan kompresi motor diesel, dan pengenalan bagian-bagian sistem bahan bakar diesel dengan kontrol elektronik (common rail system).

\section{METODE PELAKSANAAN}

\section{Tempat dan Waktu}

Kegiatan pelatihan ini akan dilaksanakan selama 4 (empat) hari, yaitu Kamis, Jumat, Sabtu dan Minggu, pada tanggal 22 sampai 25 Agustus 2019. Kegiatan dilaksanakan di Workshop Jurusan Otomotif SMK Negeri 1 Gunung Talang Kabupaten Solok.

\section{Khalayak Sasaran}

Peserta kegiatan Pelatihan Peningkatan Kompetensi Kejuruan Teknologi Motor Diesel bagi Guru dan Siswa Program Studi Teknik Otomotif SMK di Kabupaten Solokadalah SMK Negeri 1 Gunung Talang dengan jumlah peserta sebanyak 20 orang siswa dan dan 4 orang guru, dan SMK Negeri 1 Pantai Cermin sebanyak 2 orang guru, dengan jumlah total peserta pelatihan sebanyak 26 orang peserta sesuai dengan yang direncanakan sejak awal. Peserta pelatihan berasal dari program studi Teknik Otomotif, yang selama ini dengan tidak tersedianya sarana engine stand motor diesel 1 silinder. Diharapkan dari pelatihan ini, selain menambah pengetahuan dan ketrampilan, juga diberikan sertifikat yang dapat digunakan dan menjadi nilai tambah saat mereka memasuki dunia industri nantinya. Untuk lebih jelasnya peserta pelatihan dapat dilihat pada tabel 2 di bawah ini.

\section{Metode Pengabdian}

Metode yang disepakati bersama untuk pencapaian target kegiatan pengabdian Program Kemitraan Masyarakat (PKM) adalah sebagai berikut:

\section{Metode ceramah dan tanya jawab}

Metode ini digunakan untuk menjelaskan pengetahuan dan memperkenalkan jenis keterampilan yang akan diberikan. Metode ini akan ditampilkan dalam bentuk media presentasi power point. Dalam Metode ini akan disampaikan materi seperti pada tabel 1 di atas.

Tabel 2. Peserta Pelatihan Peningkatan Kompetensi Kejuruan Teknologi Motor Diesel

\begin{tabular}{llcc}
\hline No & Nama Peserta & NIS/NIP & Asal Sekolah \\
\hline 1 & ALFI YUSRA ASER & 0025576107 & SMK N 1 Gunung Talang \\
\hline 2 & ANDRI AGUS PRIANTO & 0010282105 & SMK N 1 Gunung Talang \\
\hline 3 & ARIS & 0010285979 & SMK N 1 Gunung Talang \\
\hline 4 & ARDIAN AGUSTAR & 0025474442 & SMK N 1 Gunung Talang
\end{tabular}

Persiapkan Siswa SMK Terampil melalui Pelatihan KompetensiKejuruan Teknologi Motor 
Suluah Bendang: Jurnal IImiah Pengabdian Kepada Masyarakat

Vol.19, No.1, 2019

Toto Sugiarto, Wawan Purwanto, Bahrul Amin

\begin{tabular}{clcl}
\hline 5 & DEDE TRY ANGGARA & 0038944965 & SMK N 1 Gunung Talang \\
\hline 6 & DIFIO FRASENDY & 0017477341 & SMK N 1 Gunung Talang \\
\hline 7 & ROMI PUTRA & 0028944799 & SMK N 1 Gunung Talang \\
\hline 8 & VEBY TRIO SAPUTRA & 0017832246 & SMK N 1 Gunung Talang \\
\hline 9 & YUSRI FAHMI ALWI & 0020100441 & SMK N 1 Gunung Talang \\
\hline 10 & ARISKI MINASTRI & 0010692129 & SMK N 1 Gunung Talang \\
\hline 11 & AGUNG FEBRIAN & 0006281198 & SMK N 1 Gunung Talang \\
\hline 12 & AL GAFAR ARIANTO & 0014785998 & SMK N 1 Gunung Talang \\
\hline 13 & DEDEN DEFRI SAOGO & 0022517079 & SMK N 1 Gunung Talang \\
\hline 14 & RAVEL DESRA ANYARA & 0013818645 & SMK N 1 Gunung Talang \\
\hline 15 & ARVI YULIANDRA & 0013818645 & SMK N 1 Gunung Talang \\
\hline 16 & IDRATUL DINATA & 0018081386 & SMK N 1 Gunung Talang \\
\hline 17 & JUMAIDIL SAPUTRA & 0017477706 & SMK N 1 Gunung Talang \\
\hline 18 & IQBAL CANDRA PUTRA & 00224655478 & SMK N 1 Gunung Talang \\
\hline 19 & YOGA RAHMAD HIDAYAT & 0016706261 & SMK N 1 Gunung Talang \\
\hline 20 & AIDIL SAF PUTRA & 00224655478 & SMK N 1 Gunung Talang \\
\hline 21 & DEVI HENDRI, S.Pd & 197712072009021001 & SMK N 1 Gunung Talang \\
\hline 22 & ARMAYENI, ST & 197505212007012007 & SMK N 1 Gunung Talang \\
\hline 23 & Drs. EDI YASMAN EFFENDI & 196208191988031004 & SMK N 1 Gunung Talang \\
\hline 24 & OKA SANDI PUTRA S.Pd & - & SMK N 1 Gunung Talang \\
\hline 25 & AL- AKBAR, S.Pd & 198110152010011015 & SMK N 1 Pantai Cermin \\
\hline 26 & HAFIZH ALHADI, S.Pd & 198501252010011011 & SMK N 1 Pantai Cermin \\
\hline & & & \\
\hline
\end{tabular}

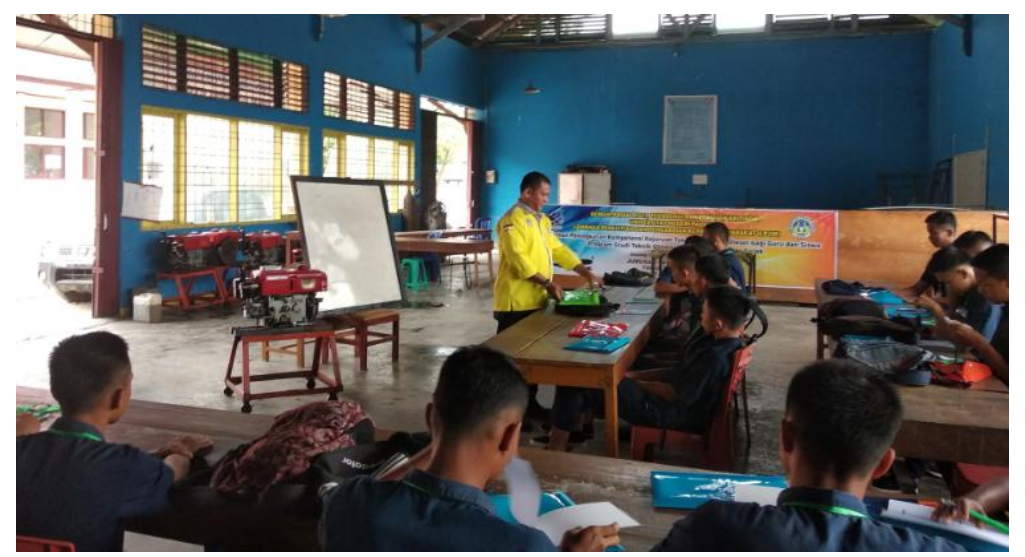

Gambar 3. Penyampaian teori pembongkaran komponen Motor diesel 


\section{Metode diskusi dan demontrasi}

Metode ini dugunakan setelah tim pelaksana selesai menyajikan materi, selanjutnya peserta pelatihan diberikan modul petunjuk praktekum. Semua peserta diarahkan untuk mempelajari modul dan dilakukan diskusi terhadap materi yang kurang dipahami.

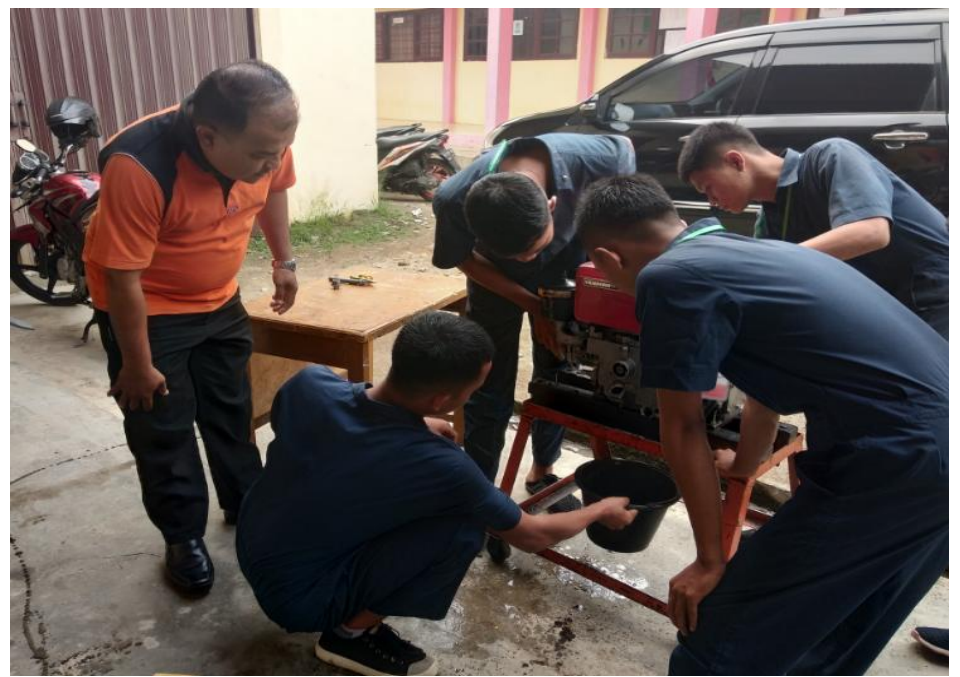

Gambar 4. Demontarsi Pembuangan oli dari motor diesel 1 silinder

\section{Metode praktekum}

Metode ini digunakan memberikan pengetahuan dan keterampilan kepada mitra untuk memperagakan bagaimana cara melakukan pekerjaan Pembongkaran dan pemasangan kepala silinder, pembongkaran dan pemasangan piston assembly, pembongkaran dan pemasangan pompa injeksi, pembongkaran dan pemasangan poros nok, pembongkaran dan pemasangan injektor, dan penyetelan saat penginjeksian, pembongkaran dan pemasangan serta penyetelan tekanan kerja injektor, menghidupkan motor diesel 4 silinder dan membuang udara dari sistem bahan bakar, pembongkaran sistem pemanas mula, pengukuran tekanan kompresi motor diesel, dan pengenalan bagian-bagian sistem bahan bakar diesel dengan kontrol elektronik (common rail system), serta Perawatan sistem bahan bakar dan tune up motor diesel.

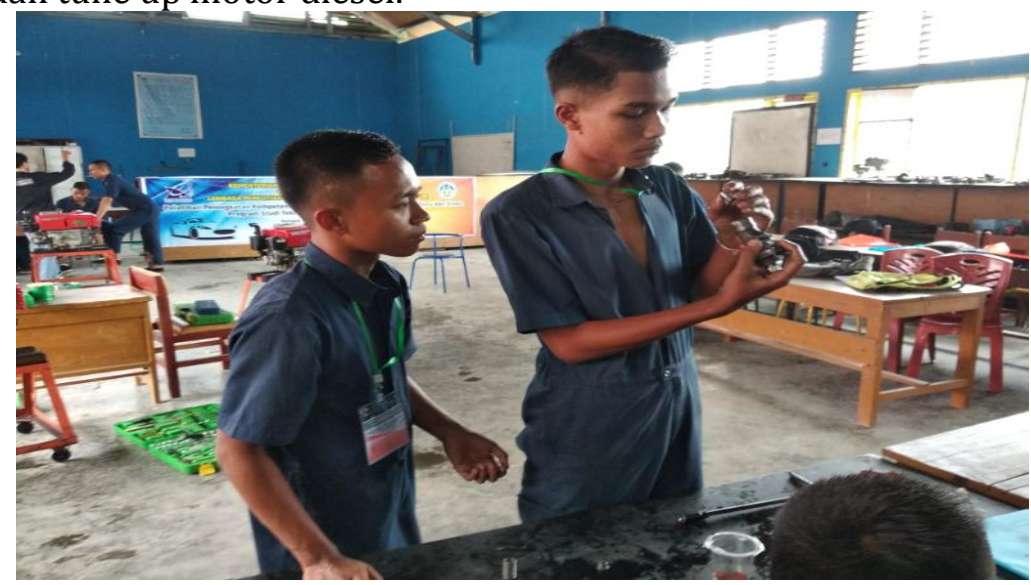

Gambar 5. Praktikum merakit pompa injeksi engine diesel

Persiapkan Siswa SMK Terampil melalui Pelatihan KompetensiKejuruan Teknologi Motor 


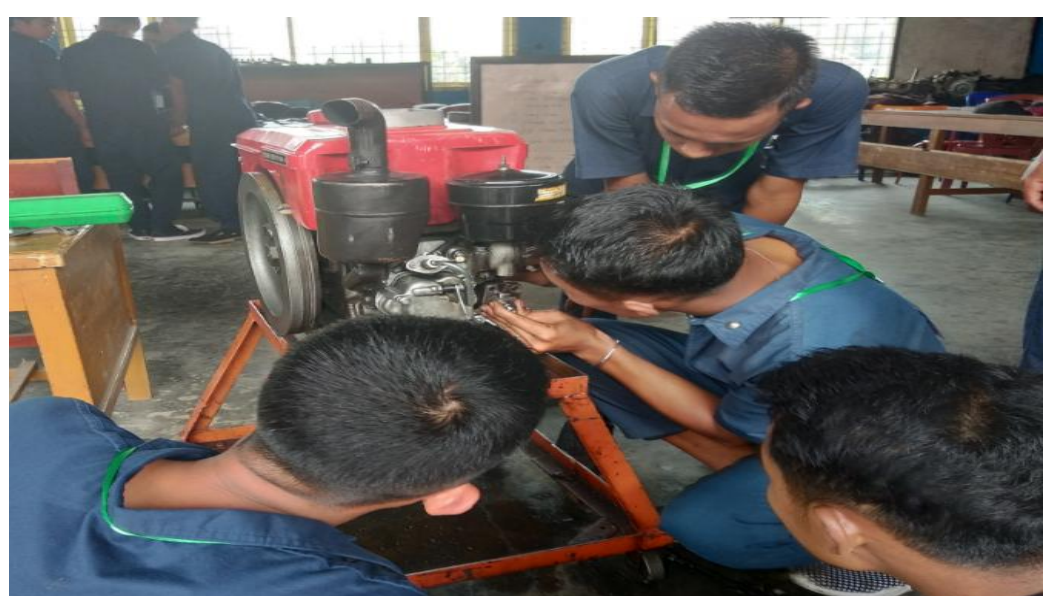

Gambar 6. Praktikum memasang pompa injeksi pada motor diesel

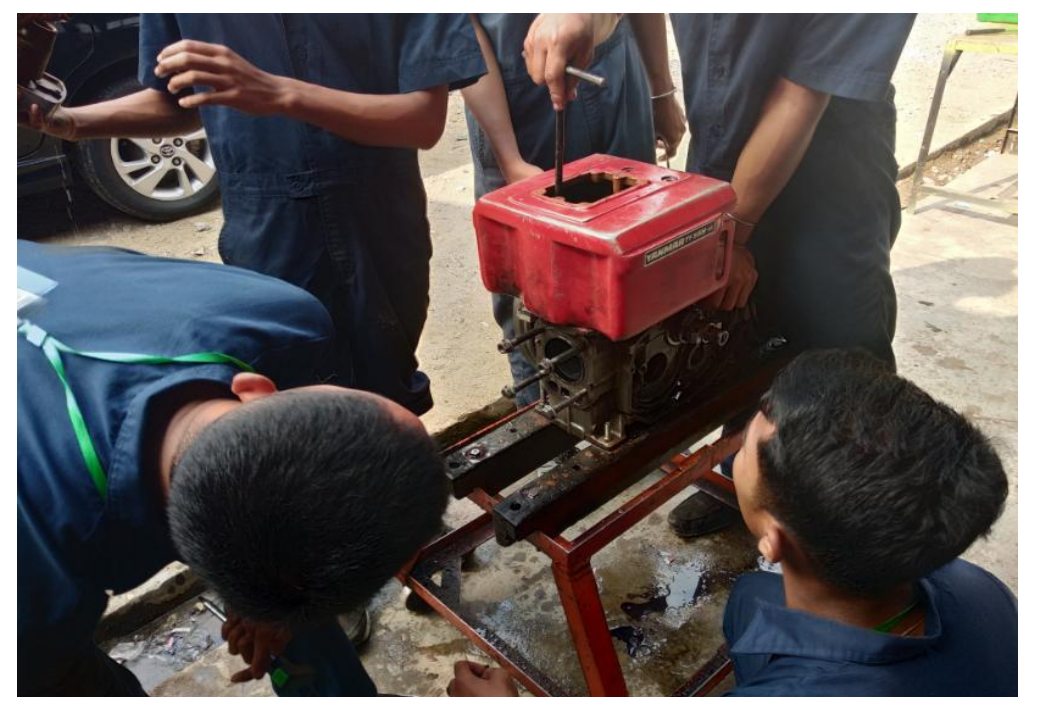

Gambar 7. Praktikum melepas radiator engine diesel

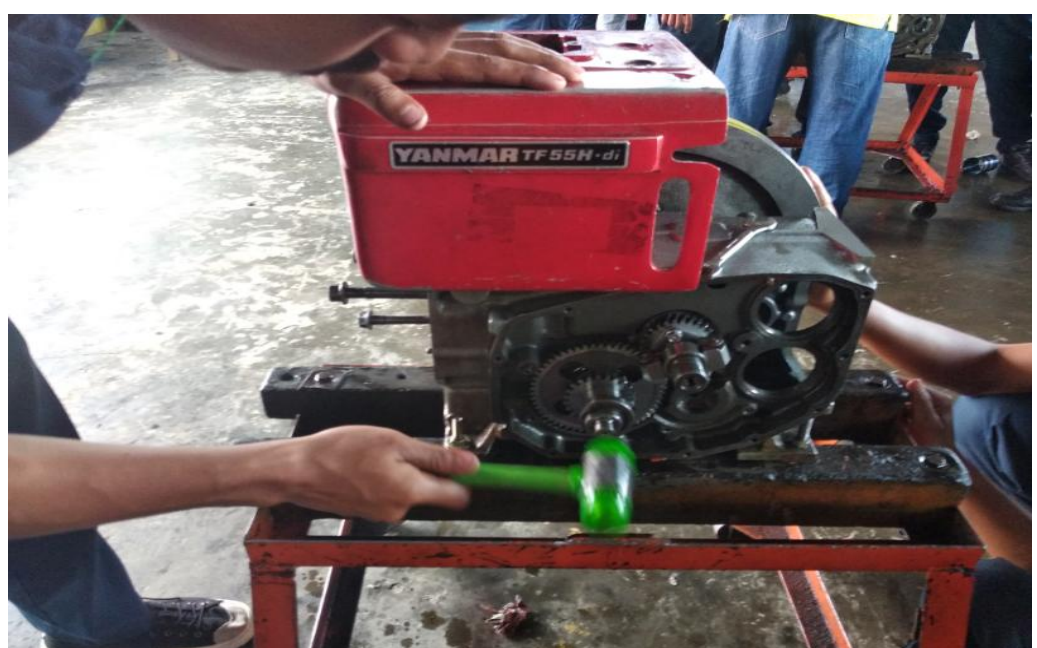

Gambar 8. Praktikum memasang poros nok engine diesel 


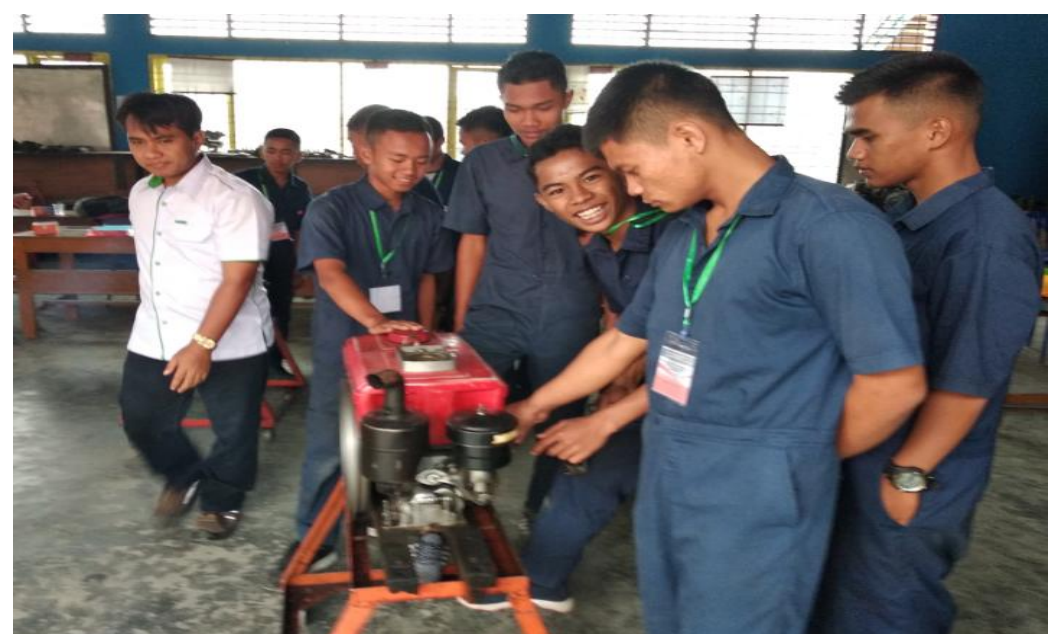

Gambar 9. Praktikum menghidupkan (mengengkol) engine diesel

\section{Indikator Keberhasilan}

Indikator keberhasilan dalam kegiatan Pelatihan Peningkatan Kompetensi Kejuruan Teknologi Motor Diesel bagi Guru dan Siswa Program Studi Teknik Otomotif SMK di Kabupaten Solok, yaitu terjadinya peningkatan pengetahuan dan ketrampilan guru dan siswa peserta pelatihan tentang Sejarah Motor Diesel, Perbedaan Motor diesel dengan motor bensin, Cara kerja motor diesel 4 langkah dan 2 langkah, Komponen-komponen utama motor diesel, Proses pembakaran motor diesel, Sistem pemasukan udara, turbo charger dan inter cooler, Sistem pelumasan dan pendinginan, Sistem Bahan Bakar Motor Diesel konvensional dan Sistem Bahan Bakar Diesel dengan kontrol elektronik (Common Rail System).

\section{Metode Evaluasi}

Metode evaluasi yang digunakan untuk mengukur keberhasilan kegiatan pelatihan Peningkatan Kompetensi Kejuruan Teknologi Motor Diesel bagi Guru dan Siswa Program Studi Teknik Otomotif SMK di Kabupaten Solok, yaitu:

1. Test awal sebelum kegiatan pelatihan dilaksanakan (Pre test), dilakukan untuk mengetahui kemampuan awal peserta pelatihan, sehingga materi pelatihan yang diberikan sesuai dengan kemampuan peserta pelatihan.

2. Test akhir setelah kegiatan pelatihan dilaksanakan (Post test), dilakukan untuk mengetahui keberhasilan kegiatan pelatihan yang telah dilaksanakan.

3. Pengamatan dan penilaian langsung saat peserta melakukan kegiatan praktikum.

\section{HASIL DAN PEMBAHASAN}

\section{Hasil Pelaksanaan}

Pelaksanaaan kegiatan "Pelatihan Peningkatan Kompetensi Kejuruan Teknologi Motor Diesel bagi Guru dan Siswa Program Studi Teknik Otomotif SMK di Kabupaten Solok", dilakukan di workshop Jurusan Teknik Otomotif SMK Negeri 1 Gunung Talang, Kabupaten Solok. Pelaksanaan kegiatan pelatihan dilaksanakan selama 4 hari, yaitu pada tanggal 22, 23, 24 dan 25Agustus 2019.

Untuk melihat hasil yang telah dicapai dilakukan evaluasi saat kegiatan berlangsung dan juga pada akhir kegiatan pelatihan.

\section{Evaluasi saat kegiatan}

Persiapkan Siswa SMK Terampil melalui Pelatihan KompetensiKejuruan Teknologi Motor 
Dilakukan melalui pengamatan saat proses pelatihan berlangsung kepada semua peserta pelatihan oleh instruktur pelatihan meliputi : kehadiran, sikap, dan aktifitas peserta.

a. Kehadiran Jumlah peserta yang mengikuti pelatihan adalah 26 orang dari 20 orang yang direncanakan. Semua peserta dapat mengikuti pelatihan dari awal kegiatan sampai akhir kegiatan, mulai pukul 08.00 sampai dengan 17.00.

b. Sikap dan antusias peserta selama pelatihan sangat tinggi, peserta tidak ada yang meninggalkan pelatihan dan selalu disiplin mematuhi jadwal pelatihan yang telah dibuat. Bahkan jadwal pelatihan yang direncanakan awalnya hanya sampai jam 16.30, bertambah 30 menit, dikarenakan peserta sangat semangat untuk mencoba menghidupkan motor diesel.

c. Keingintahuan peserta sangat tinggi, ini terlihat dari pandangan peserta saat materi diterangkan, semuanya peserta bisa fokus dan kegiatan berjalan tertib seperti yang direncanakankan, yakni saat instruktur menerangkan materi, semua peserta harus memperhatikan instruktur dan materi, dan pada saat diberikan kesempatan untuk melakukan apa yang didemonstrasikan instruktur, peserta pelatihan dapat melihat modul yang sudah diberikan jikalau lupa langkah-langkah yang diterangkan instruktur ataupun bertanya kepada tim panitia.

d. Tidak ada peserta pelatihan yang berdiam diri selama kegiatan berlangsung; peserta pelatihan yang telah berhasil menyelesaikan tugasnya, mereka akan membantu peserta lain yang masih belum bisa. Hal ini juga memupuk semangat kebersamaan dan saling bantu membantu diantara peserta pelatihan, bahkan mereka menjadi saling kenal dan dekat meskipun sebelumnya mereka ada yang belum kenal karena asal sekolah yang berbeda.

\section{Evaluasi Akhir kegiatan}

Evaluasi akhir kegiatan dilakukan dengan melihat hasil ujian yang dilakukan pada hari terakhir pelatihan. Hasil ujian dibandingkan dengan kemampuan awal peserta pelatihan sebelum pelatihan diberikan. Untuk memudahkan melihat apakah kegiatan ini memberikan dampak yang signifikan terhadap peserta, dapat dilihat pada tabel 3. Berdasarkan tabel 3, terlihat terjadinya peningkatan kemampuan peserta pelatihan. Rata-rata nilai peserta sebelum dilakukan pelatihan adalah 67,75 dan setelah dilakukan pelatihan kemampuan peserta meningkat menjadi 77,13. Artinya pelatihan yang diberikan dari tanggal 22, 23, 24, dan 25Agustus 2019 dapat meningkatkan kemampuan peserta sebesar 15,45\% dalam kompetensi kejuruan teknologi motor diesel bagi guru dan siswa SMK di kabupaten Solok.

Tabel 3. Nilai peserta pelatihan sebelum dan setelah mengikuti pelatihan kompetensi Teknologi Motor Diesel

\begin{tabular}{llccc}
\hline \multirow{2}{*}{ No } & \multirow{2}{*}{ Nama Peserta } & Nilai Sebelum & Nilai Sesudah & \multirow{2}{*}{ \% Naik } \\
\cline { 3 - 4 } & & Pelatihan & Pelatihan & \\
\hline 1 & ALFI YUSRA ASER & 70 & 80 & 14.29 \\
\hline 2 & ANDRI AGUS PRIANTO & 75 & 83 & 10.67 \\
\hline 3 & ARIS & 68 & 75 & 10.29 \\
\hline 4 & ARDIAN AGUSTAR & 76 & 80 & 5.26 \\
\hline 5 & DEDE TRY ANGGARA & 75 & 84 & 12.00 \\
\hline 6 & DIFIO FRASENDY & 70 & 77 & 10.00 \\
\hline 7 & ROMI PUTRA & 71 & 80 & 12.68 \\
\hline 8 & VEBY TRIO SAPUTRA & 72 & 80 & 11.11 \\
\hline 9 & YUSRI FAHMI ALWI & 65 & 75 & 15.38
\end{tabular}




\begin{tabular}{llccc}
\hline 10 & ARISKI MINASTRI & 66 & 77 & 16.67 \\
\hline 11 & AGUNG FEBRIAN & 65 & 75 & 15.38 \\
\hline 12 & AL GAFAR ARIANTO & 67 & 76 & 13.43 \\
\hline 13 & DEDEN DEFRI SAOGO & 73 & 90 & 23.29 \\
\hline 14 & RAVEL DESRA ANYARA & 66 & 74 & 12.12 \\
\hline 15 & ARVI YULIANDRA & 64 & 76 & 18.75 \\
\hline 16 & IDRATUL DINATA & 63 & 75 & 19.05 \\
\hline 17 & JUMAIDIL SAPUTRA & 65 & 77 & 18.46 \\
\hline 18 & IQBAL CANDRA PUTRA & 63 & 76 & 20.63 \\
\hline 19 & YOGA RAHMAD HIDAYAT & 64 & 77 & 20.31 \\
\hline 20 & AIDIL SAF PUTRA & 66 & 75 & 13.64 \\
\hline 21 & DEVI HENDRI, S.Pd & 64 & 76 & 18.75 \\
\hline 22 & ARMAYENI, ST & 66 & 75 & 13.64 \\
\hline 23 & Drs. EDI YASMAN EFFENDI & 71 & 88 & 23.94 \\
\hline 24 & OKA SANDI PUTRA S.Pd & 72 & 90 & 25.00 \\
\hline 25 & AL- AKBAR, S.Pd & 74 & 82 & 10.81 \\
\hline 26 & HAFIZH ALHADI, S.Pd & 75 & 90 & 20.00 \\
\hline & Rata-rata & 67.75 & 77.13 & \\
\hline & & & & $15.45 \%$
\end{tabular}

Berdasarkan tabel 3 di atas dapat diilustrasikan ke dalam bentuk grafik seperti gambar 10 di bawah ini.

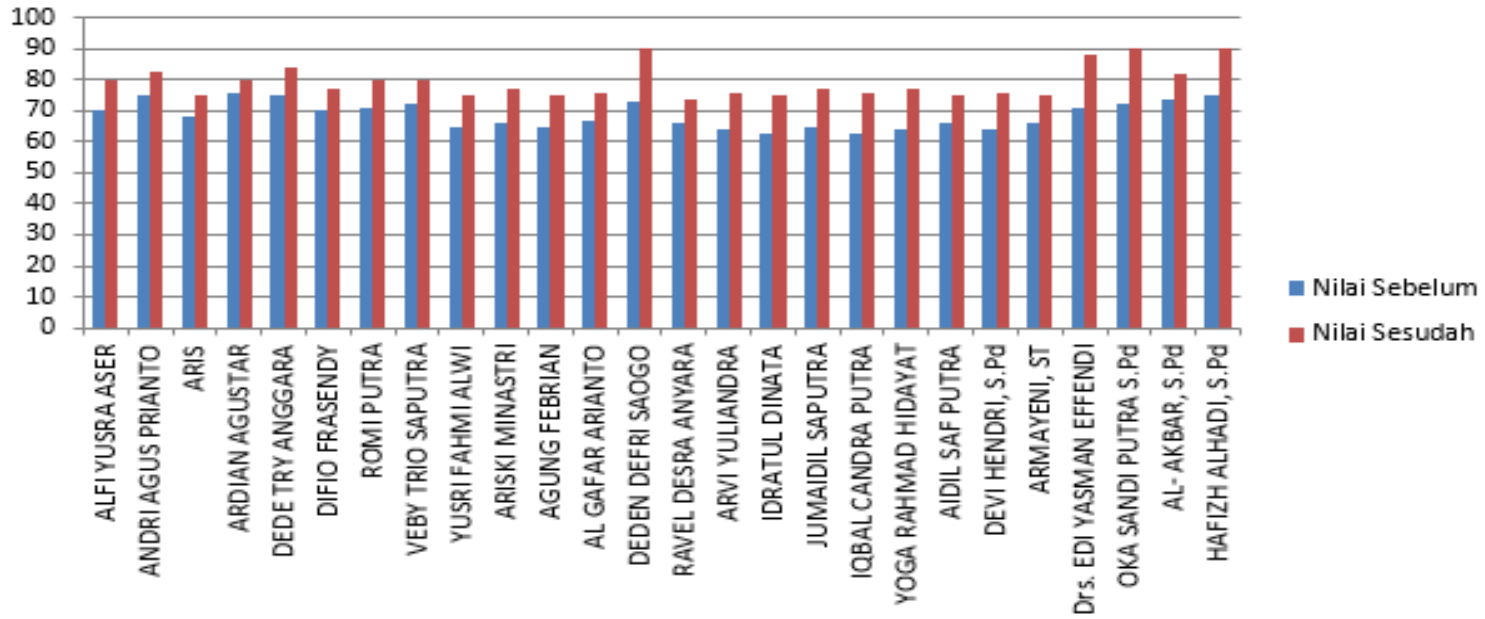

Gambar 10. Grafik peningkatan kemampuan peserta pelatihan teknologi motor diesel

\section{KESIMPULAN}

Luaras dari kegiatan Pengabdian Kepada Masyarakat (PKM) selain dari jasa pelatihan, juga menghasilkan modul pelatihan dan modul praktikum, publikasi ilmiah kegiatan pengabdian kepada masyarakat Program Kemitraan Masyarakat pada jurnal ilmiah, dam publikasi kegiatan pengabdian kepada masyarakat Program Kemitraan Masyarakat pada media 
masa (surat khabar/koran daerah), serta dapat meningkatkan motivasi guru dan siswa SMK program studi Teknik Otomotif di Kabupaten Solok untuk meningkatkan dan mengembangkan keterampilannya di bidang otomotif, terutama bidang Teknologi Motor Diesel yang perkembangannya sangat pesat pada kendaraan.

Kegiatan pelatihan teknologi motor diesel sangat dibutuhkan oleh SMK-SMK, karena masih belum tersedianya peralatan yang terkait dengan teknologi motor diesel, sehingga banyak sekolah ataupun guru yang tidak menyampaikan materi pembelajaran teknologi motor diesel.

\section{DAFTAR PUSTAKA}

J. Trommelmans. (2012). Mesin Disel. Prinsip-prinsip mesin disel untuk otomotif. Penerbit PT. Rosda Jaya Putra. Jakarta.

Mitsubishi. (2010). Workshop Manual Mitsubishi COLT Solar ENGINE \& CHASIS. PT. Krama Yudha Tiga Berlian Motors. Jakarta.

PPPGT. (2010). Motor Diesel. Modul Pelatihan Otomotif Dasar Program Studi Mesin Otomotif. Pusat Pengembangan Penataran Guru Teknologi. VEDC. Malang.

PPPGT. (2010). Sistem Bahan Bakar Motor Diesel. Pusat Pengembangan Penataran Guru Teknologi. VEDC. Malang.

Presiden RI (2003). Undang Undang no 20 Tahun 2003 tentang Sistem Pendidikan Nasional. Jakarta.

Toyota. (2010). Training Engine Step I. PT. Toyota Astra Motor. Jakarta.

Wawan purwanto,dkk. (2012). Analisa kerja Manifold Absolute Pressure (MAP) pada D-EFI dan Mass Air Flow Sensor (MAFS) pada L-EFI serta emisi yang dihasilkan oleh kedua sistem EFI tersebut. FT. UNP. Hasil Penelitian di Fakultas Teknik Universitas Negeri Padang.

Wiranto Arismunandar. (2003). Motor Diesel Putaran Tinggi. PT. Pradnya Paramita. Jakarta.

YANMAR. (2012). Perbaikan dan pemeliharaan Motor Diesel Yanmar Model Seri TF 55-300. PT. Yanmar Diesel Indonesia. Jakarta. 